\title{
Self-Monitoring in L2 Writing by Spanish Secondary School Students
}

\author{
Rocío Menárguez Sarabia, Florentina Nicolás and \\ Julio RocA DE LARIOS \\ Universidad de Murcia
}

Received: 5 June 2011 / Accepted: 8 September 2011

ISSN: $1697-7467$

\begin{abstract}
Although teacher feedback is generally considered to play an important role in the development of students' writing abilities, recent research is increasingly showing that its effectiveness very much depends on how well it matches students' concerns. One technique especially suitable to determine these concerns is to encourage students to self-monitor their own written production by means of annotations. In this study, we analyzed the annotations made by two groups of EFL secondary school students at different levels of proficiency while writing an expository text. Both groups used requests for translation as the basic annotation technique and their annotations were mainly focused on syntax and lexis, but proficiency-related differences were also found in the average number of annotations made and in the attention paid to discourse and organization. These findings are empirically discussed and a number of pedagogical recommendations are suggested.
\end{abstract}

Keywords: Self-monitoring; annotations; secondary school students; proficiency leve; L2 writing.

Automonitorización en la escritura de una lengua extranjera por estudiantes españoles de secundaria

RESUMEN: Aunque los comentarios escritos y las correcciones de los profesores se consideran recursos didácticos importantes para que los estudiantes puedan desarrollar adecuadamente su habilidad escritora, estudios recientes demuestran que la efectividad de dichos comentarios y correcciones depende en gran medida de cómo se relacionen con las preocupaciones de los aprendices. Una técnica especialmente adecuada para determinar estas preocupaciones consiste en animar a los estudiantes a que monitoricen su propia producción escrita por medio de anotaciones. En este estudio se analizaron las anotaciones realizadas por dos grupos de estudiantes con distinto dominio del inglés como lengua extranjera en un instituto de educación secundaria mientras componían un texto expositivo por escrito. Ambos grupos utilizaron la petición de traducción como forma de anotación predominante y centraron sus anotaciones en cuestiones de léxico y de sintaxis. Las diferencias entre los dos grupos se centraron fundamentalmente en el promedio de anotaciones realizadas y en la atención prestada al discurso y a la organización del texto. Estos resultados se interpretan desde una perspectiva empírica y se utilizan como punto de partida para sugerir diversas recomendaciones pedagógicas.

Palabras clave: Monitorización; anotaciones; estudiantes de secundaria; nivel de dominio de la L2; escritura en segundas lenguas. 


\section{INTRODUCTION}

It is generally acknowledged that one important function of feedback on L2 writing is to provide learners with opportunities to help them notice the gap between their own productions and the target language (Sachs \& Polio, 2007, van Beuningen, 2010). However, the effectiveness of feedback when given in the form of error correction (EC) has been subject to a number of criticisms that include (i) the theoretical arguments against grammar correction proposed by Truscott (1996, but see counterarguments by Ferris, 1999, 2004); (ii) the lack of clarity or accuracy that can sometimes be found in teachers' corrections (Cohen \& Cavalcanti, 1990); (iii) the minimal processing EC is supposed to require from learners as compared to other forms of feedback (Adams, 2003; Hedgcock and Lefkowitz, 1994); (iv) the difficulties often experienced by writers in finding out out what is non-target-like in their output due to the often confusing quantity of written marks EC involves (Hyland, 1998); or (vi) the unsettled nature of findings regarding particular types of EC (Ellis et al., 2008; van Beuningen, 2010).

Different alternatives have been suggested to this state of affairs. One of them involves the use of self-monitoring techniques by means of which students may report their needs and concerns while writing their compositions so that the teacher may have access to these self-reported concerns before s/he engages in the actual feedback process. However, as compared to the attention played to peer evaluation, for example, the analysis of self-monitoring has practically been neglected in second language writing research. With a view to assessing its strengths and weaknesses, the present study was intended as an exploration of student annotations, one of the most commonly used selfmonitoring techniques, in the context of a Spanish secondary school.

In what follows, we will first present the necessary background to the empirical study. Given the importance of students' expectations for teacher feedback to be effective, a discussion of the different factors involved in this issue will be presented as well as a brief description of the different procedures used to gather information about learners' perceptions of teacher feedback. The theoretical and practical significance of one of these procedures, i.e., self-monitoring annotations, will then be highlighted. Finally, after a brief review of the few empirical studies on the use of annotations, our empirical study will be fully reported.

\subsection{Students' expectations and perceptions of teacher feedback}

An important area of concern about the effectiveness of teacher response to writing is related to the type of feedback student writers expect to receive from their instructors, the assumption being that if these expectations are taken into account feedback may substantially be improved (Hyland, 2003). In addition to motivation (Goldstein, 2006), the most important factors generally considered to play a part in shaping students' expectations toward feedback are their L2 proficiency level and their learning beliefs and goals.

Some scholars (see, for instance, Storch \& Tapper, 1996; Truscott, 1996) have drawn attention to the importance of students' level of proficiency for feedback to be effective. It is posited that teacher feedback will be more useful if the information in his/her comments is in accordance with students' developmental readiness to receive and process 
it. Sharwood Smith (1991), for example, pointed out that "externally induced errors", i.e., errors identified by the teacher, may not be registered by the L2 writer or may not influence the learning process if the learner is not "ready" for this information.

In addition to developmental readiness, other personal factors seem to influence the retention of written feedback by students. These factors include learners' beliefs and attitudes toward the form of feedback received and their goals about learning. Storch \& Wigglesworth (2010), for example, found that the advanced ESL learners in their study did not adopt some forms suggested by the teacher in the reformulation of their texts. The students felt that the alternatives provided were not necessarily better expressions than those in their original texts or thought that they contradicted their beliefs of what constituted a good writing style. The authors concluded that these affective factors, normally shaped by previous instructional experiences, are often ignored in spite of the fact that they influence not only "the type of strategies learners adopt in dealing with the feedback received but also their willingness to accept the feedback and their likehood of retaining it" (p. 328).

The effectiveness of feedback should thus be contemplated in connection with this variety of factors. Bearing this in mind as well as the attested fact that most learners overwhelmingly welcome being responded by the teacher (Leki, 1991; Zhang, 1995), it may safely be concluded that, when providing feedback, teachers should look not only into the linguistic characteristics of the texts reviewed but also into learners' expections. In this respect, different scholars (Cumming, Busch \& Zhou, 2002; Sachs \& Polio, 2007) have called for research that looks into these expectations in natural classroom contexts. This is the path we have attempted to follow in the present study.

\subsection{Procedures used to know about sudents' perceptions of teacher feedback}

A number of different procedures have been used to uncover students' preferences for the feedback they wish to receive from their instructors and the strategies they use to process that feedback. One of these procedures involves the use of surveys, but surveys, according to Leki $(1990,1991)$, tend to include questions that direct learners' attention to language errors rather than content and text structure. Respondents may thus appear to show a greater interest in errors than they may normally feel and, consequently, there is a need to find out more about other areas of writing about which students may wish to receive teacher feedback comments.

Goldstein (2004) suggested that a very useful way to address this issue would be to ask students to write autobiographies in which they might include descriptions as complete as possible of the feedback types they received from previous teachers, what they liked and did not like about those types and what they did after receiving the feedback. Teacher-student conferences have also been suggested as a useful procedure to discuss students' dilemmas and clarify where feedback has not been understood. However, these two procedures of collecting data are limited in that they only provide students' retrospective accounts (autobiographies) or are very costly in terms of time and personal resources (conferences).

A more practical alternative involves the use of written notes by students through which they can inform their teachers on how they used or addressed their feedback, what 
comments they found difficult to understand, what they could understand but did not know how to use for revision or what they decided not to attend and why. Such procedures allow for effective communication to take place between students and teachers and may hopefully encourage students to use their teachers' feedback thoughtfully and critically.

However, a common characteristic of these methodological procedures is that they are normally used to find out about students' reactions to teachers' feedback and, as a result, are of little help for teachers to work out what their students are saying in their texts. As suggested by Goldstein (2004), this lack of knowledge about students' intentions, which is supposed to be one of the most important causes of teachers' misuderstandings and of their subsequent provision of inappropriate responses, might be avoided, at least partially, if students informed their instructors about aspects of their own writing while composing their texts. Although teachers could still give feedback on items not mentioned by the students, they might also gear part of that feedback to those student-generated comments and thus give students the chance to gain responses to issues that they consider worthy of note.

One way to gain insights into students' perceptions is by giving them control over the initiation of feedback through self-monitoring techniques. In practical terms, this means that students are invited to make annotations on the problems they experience while composing, to which the teacher is supposed to respond. The continuous process of give and take between the students and the teacher makes reviewing through selfmonitoring a truly interactive task, similar in some respects to peer evaluation. However, as compared to peer evaluation, which has been extensively investigated, self-monitoring has been practically neglected (Cresswell, 2000). And yet, self-monitoring deserves attention because, in addition to its alledged pedagogical benefits, it is theoretically sustained by two important SLA constructs, namely output production and noticing.

Pedagogically, by allowing students to identify specific language problems as well as their intended ideas, self-monitoring may "remove the worry of the block" (Cresswell, 2000: 236) and encourage learners to move on with their compositions in the hope that the teacher will help them with their language needs. Teachers may, in turn, precise their advice by taking into account the points previously singled out by the students in their annotations and direct their responses toward those black spots that may lead them to abandon or simplify their intended messages. On the other hand, the activation of selfmonitoring may be theoretically accounted for if we consider students as engaged in output processes (through their production of written language) and noticing processes (becoming aware of their ideational, linguistic or textual needs). Swain (1995 and elsewhere) holds that output forces learners to process language with more mental effort than input. According to this assumption, output is seen not only as the end product of acquisition but also as an important step towards L2 learning, or, to put it differently, as the necessary mediation from understanding the language to using it. Therefore, the more opportunities learners have of producing output, the more chances they will have to learn the language. Output is also seen as a trigger that makes learners become aware of their production problems and notice language forms. Noticing in turn means becoming consciously aware of linguistic forms and it is considered, at least by some authors (Robinson, 1995; Schmidt, 2001), as an essential process for L2 learning to take place. 
Framed in this theoretical line of inquiry, the study to be reported below is intended to add to the existing research on students' self-monitoring in writing. To do so, the data have been collected from adolescent, secondary school students (a population which has not been prominent in previous studies), in a new learning context (a foreign language setting), and with some slightly modified conditions from those of previous research. A review of the previous empirical work on students' annotations follows as the necessary background to our empirical study.

\subsection{Empirical research on students' annotations}

In what follows, we shall briefly review the four studies that, to the best of our knowledge, have addressed the issue of self-monitoring in L2 writing, either from a descriptive (Storch \& Tapper, 1996; Storch \& Tapper, 1997) or an interventionist perspective (Cresswell, 2000; Xiang, 2004). The motivation and objectives of the studies, their contexts and participants, their data collection procedures and their main results will be briefly reported.

A number of different reasons have motivated these studies. In the case of the descriptive studies, the reasons include the lack of benefits associated with traditional error correction as well as the fact that this form of feedback tends to be inconsistent, uninformative and often unclear. The interventionist studies have, in turn, been triggered by the attempt to counteract students' limitations to articulate their concerns when selfmonitoring (Cresswell, 2000), or by the attested lack of effectiveness of teachers' traditional comments (Xiang, 2004). The four studies suggest that teacher feedback might be more useful if it were more closely related to students' perceptions of their own writing. So students are encouraged to use annotation schemes (descriptive studies) or trained to use them skillfully (interventionist studies) so that they can act as reviewers of their own work.

Other important aspects to be highlighted are the contexts in which these studies have been conducted and the participants taking part in them. In Storch and Tapper's study (1996), the participants included a group of ESL undergraduates at an Australian university who were fairly representative of the entire population of international students in terms of residence status, cultural background, length of stay, academic discipline and writing proficiency in English. One year later Storch and Tapper (1997) carried out their study in the same university, but this time the partipants included non-native (NNS) and native speakers (NS) from a range of different faculties. In the study by Cresswell (2000) the participants were seven adult Italians studying for the Cambridge Proficiency test at a language school in Italy. Finally, two classes of English majors attending a course on English writing at a university in Eastern China participated in the study carried out by Xian (2004).

The data collection procedures also varied across studies. Storch and Tapper (1996) invited students to make annotations about any specific item of their choice while writing their regular compositions over two semesters. A questionnaire was also handed out to all the students in order to collect their perceptions about the journal annotation scheme. In the 1997 study, the students were asked to write an argumentative research paper of 1500-2000 words and annotate their comments either on an annotation sheet or on the 
essay drafts. Annotations were entirely voluntary and subsequent writing conferences with the teachers were held to provide students with feedback. Cresswell (2000) asked his participants to write four self-monitored compositions of about 350 words each over a period of 4 weeks. While the first two compositions were used for training purposes, the annotations of the last two were examined to explore how much attention was paid by the students to global content and organization. Post-task questionnaires and recorded semi-structured interviews were also used to elicit the students' views of the selfmonitoring technique and to gather information about their approaches to composing. Finally, the study by Xiang (2004), which used a pre- post-task design, involved the completion of four writing tasks, a questionnaire and an interview. The students in the experimental group (EG) were required to make annotations on their drafts, while the students in the control group (CG) were not. Instead they were asked to write a short essay of about 150-200 words every two weeks about anything that was of interest to them. Near the end of the course, a questionnaire aimed to investigate the participants' attitudes towards self-monitoring was given to the EG and interviews were conducted with nine EG students.

As for results, Storch and Tapper (1996) found that their participants made a total of 255 annotations in 39 journal entries, although there was a great deal of individual variation. Two students, for example, annotated 9 journal entries per person while five students only annotated one entry each. Syntax and lexis were the most frequent areas of annotation. In the 1997 study, the 15 NNS students made a total of 121 annotations while the 10 NS made a total of 75 annotations. Generally, the most frequent NNS' positive comments were related to structure followed by content while those of the NSs focused basically on content. This was found to be an important difference in students' concerns that raises interesting questions about the relationship between language proficiency and self-asessment of writing. Cresswell (2000) found that three quarters of students' annotations were concerned with language and that the proportion of language-focused annotations evoking positive teacher feedback was $51 \%$. Self-monitoring was thus shown to provide a suitable context to support growth of students' productive language resources. In addition, the study suggested that learner training in the self-monitoring technique deserves wider consideration as a way of increasing student autonomy and teacher responsiveness to individual needs. Finally, the study by Xiang (2004) showed that participants generally managed to use self-monitoring effectively so that the teacher might learn about the problems they encountered in writing. The technique was also found to be especially learnable for self-monitoring on organization and highly helpful for high achievers.

\section{The STUDY}

Building on previous research on students' annotations, the exploratory study reported below was intended to shed further light on self-monitoring in L2 writing through the analysis of the annotations made by adolescent, secondary-school EFL learners at two levels of L2 proficiency. The students were asked to write a composition and simultaneously given the opportunity to annotate all types of problems they noticed when composing their texts. The research questions posed in the study included the following: 
RQ1. What form do students' annotations take?

RQ2. What are the similarities and differences in the form of the annotations made by secondary school students at different levels of proficiency?

RQ3. What aspects of writing concerned the students most?

RQ4. What are the similarities and differences in the content of the annotations made by secondary school students at different levels of proficiency?

\section{Method}

The research project was carried out with two EFL intact classes (4th ESO and 1st Bachillerato) at the Francisco Cascales High School in Murcia (Spain). Both classes were taught by the same teacher, who used a traditional teaching methodology based on the systematic coverage of the activities included in the students' textbooks occasionally supplemented with song listening or video watching extra-activities. The participants in the study were 204 th ESO students and 30 1st Bachillerato students (BAC students henceforth) whose average age was respectively 15 and 16. According to their teacher, the BAC students' command of English was higher than that of the ESO students.

\subsection{Data collection}

Both groups were asked to write an argumentative essay entitled "What would I do if I won the lottery?". The students wrote their essays in ordinary class hours and, before the writing activity was initiated, they were instructed to annotate any doubt or problem that came to their minds before, while or after composing their texts. They were asked to make the annotations in the margins of the sheet of paper they would use for writing their essays and were also provided with illustrations of what the annotations might look like. It was also made clear to the students that the purpose of the annotations was for the teacher to know about their writing concerns before giving them feedback on the compositions they were about to write. Thus, they were asked to be honest and thorough in the expression of those concerns since they would not be evaluated at all in terms of quantity or quality. A maximum of 45 minutes was set for the joint completion of the writing and the annotation activities. All students completed both tasks during this time limit.

Once these activities had been completed, the students were given three questions in Spanish:

What do you think about this technique? Why?

Has this system helped you to improve the expression of ideas? Why?

Has this technique helped you to realise of the skills about which you have more doubts?

These questions were intended to elicit students' perceptions about the usefulness of the annotation technique. They were asked to answer in Spanish and given 10 minutes to do so. 


\subsection{Data Analysis}

The written drafts were examined for all instances of annotations, which were then counted for each student. The analysis of these data involved two stages: deciding on the coding categories and sub-categories to be used, and then coding each annotation from each student. The coding categories used were elaborated from those suggested by Storch and Tapper (1996) and the coding process involved the iterative examination of the data until finally a category and sub-category was assigned to each individual annotation.

The students' perceptions on the usefulness of the technique, as apparent in their responses to the three questions in Spanish mentioned above, were thematically grouped and used only as a secondary data source to make sense of the primary data.

\section{RESUlts}

The findings of the study are presented as responses to the research questions mentioned above.

\section{RQ1: What form do the students' annotation requests take?}

The analysis of the form of students' annotations revealed that they fell into six major categories, as shown in Table 1:

Table 1. Form of students' annotations across groups.

\begin{tabular}{|l|c|c|}
\hline \multicolumn{1}{|c|}{ CATEGORIES } & $\begin{array}{c}\text { NUMBER OF } \\
\text { ANNOTATIONS }\end{array}$ & $\begin{array}{c}\text { PERCENTAGE OF } \\
\text { ANNOTATIONS }\end{array}$ \\
\hline A request for a translation & 155 & $60,78 \%$ \\
\hline $\begin{array}{l}\text { A request for the correction of } \\
\text { a translation }\end{array}$ & 41 & $16,08 \%$ \\
\hline $\begin{array}{l}\text { A request for the correction of } \\
\text { an L2 form }\end{array}$ & 32 & $12,55 \%$ \\
\hline $\begin{array}{l}\text { Which of the alternatives is } \\
\text { correct? }\end{array}$ & 15 & $5,88 \%$ \\
\hline $\begin{array}{l}\text { Is there another way to say } \\
\text { this? }\end{array}$ & 8 & $3,14 \%$ \\
\hline A blanket request & 4 & $1,57 \%$ \\
\hline
\end{tabular}

1. A request for a translation was the most frequent form of annotation $(60,78 \%)$ and involved the translation of an L1 item into the L2:

\section{Student text}

If I won the lottery, I would buy
Annotation

“Cómo se dice yate?" 
2. A request for the correction of a translation was the second most frequent annotation $(16,08 \%)$ and asked for the correction of a direct translation from the L1:

\section{Student text}

"...I would buy all the mode..."

\section{Annotation}

"No sé si la moda es the mode"

3. A request for the correction of an L2 form appeared in $12,55 \%$ of the annotations made by the students:

\section{Student text}

"..and I would phone to all my family..."

\section{Annotation}

"No sé si phone to está bien dicho"

4. Which of the alternatives is correct? Some annotations $(5,88 \%)$ involved asking for the correction of the alternatives provided by the students:

\section{Student text}

“...I would buy a yatch with

a lot/of beautiful girls"

\section{Annotation}

“¿Cuál de las dos es correcta: a lot beautiful girls o a lot of beautiful girls?"

5. Is there any other way to say this? There were a few annotations $(3,13 \%)$ through which the students asked if there was another way of saying something:

\section{Student text}

"If I won the lottery, I would travel

to a lot of places, because there are a lot of that I want to visit."

\section{Annotation}

“¿Existe algún sinónimo para decir lugares, sitios?"

6. Blanket request. The students asked for items in a particular field or for the correction of the whole composition:

\section{Student text}

\section{Annotations}

"No sé si mi redacción está bien estructurada"

RQ2: What are the similarities and differences in the form of the annotations made by secondary school students at different levels of proficiency?

As can be seen in Table 2, both ESO and BAC students used similar percentages of forms to formulate their annotations. Asking the teacher for the translation of an item previously formulated in the L1 was the most frequent form of annotation in both groups ( $\mathrm{ESO}=56 \%$; $\mathrm{BAC}=62,78 \%$ ), the next two most frequent forms respectively involving requests for the correction of a translation $(\mathrm{ESO}=20 \%$; $\mathrm{BAC}=14,44 \%)$ and of an $\mathrm{L} 2$ form $(\mathrm{ESO}=14,67 \%$; $\mathrm{BAC}=11,67 \%)$. A few annotations asked which of the alternatives provided by the students was correct $(\mathrm{ESO}=5,33 \%$; $\mathrm{BAC}=6,11 \%)$, a small number was related to whether there were other ways of expressing the intended meaning $(\mathrm{ESO}=2,67 \%$; $\mathrm{BAC}=3,33 \%)$ and, finally, an extremely reduced number of annotations was coded as blanket requests $(\mathrm{ESO}=1,33 \%$; $\mathrm{BAC}=1,67 \%)$. 
Table 2. Form of ESO and BAC' students' annotations

\begin{tabular}{|l|c|c|c|c|}
\hline \multirow{2}{*}{ CATEGORY } & \multicolumn{2}{|c|}{ ESO STUDENTS' ANNOTATIONS } & \multicolumn{2}{c|}{ BAC STUDENTS' ANNOTATIONS } \\
\cline { 2 - 5 } & NUMBER & PERCENTAGE & NUMBER & PERCENTAGE \\
\hline $\begin{array}{l}\text { Request for a } \\
\text { translation }\end{array}$ & 42 & $56 \%$ & 113 & $62,78 \%$ \\
\hline $\begin{array}{l}\text { Request for } \\
\text { the correction } \\
\text { of a } \\
\text { translation }\end{array}$ & 15 & $20 \%$ & 26 & $14,44 \%$ \\
\hline $\begin{array}{l}\text { Request for } \\
\text { the correction } \\
\text { of an L2 form }\end{array}$ & 11 & $14,67 \%$ & 21 & $11,67 \%$ \\
\hline $\begin{array}{l}\text { Request for } \\
\text { the correct } \\
\text { form between } \\
\text { alternatives }\end{array}$ & 4 & $5,33 \%$ & 11 & $6,11 \%$ \\
\hline $\begin{array}{l}\text { Request for } \\
\text { synonyms }\end{array}$ & 2 & $2,67 \%$ & 6 & $3,33 \%$ \\
\hline $\begin{array}{l}\text { A blanket } \\
\text { request }\end{array}$ & 1 & $1,33 \%$ & $\mathbf{1 8 0}$ & $1,67 \%$ \\
\hline TOTAL & $\mathbf{7 5}$ & $100 \%$ & $\mathbf{6}$ & \\
\hline MEAN & $\mathbf{3 , 7 5}$ & & 2,98 & \\
\hline $\begin{array}{l}\text { Standard } \\
\text { Deviation }\end{array}$ & 2,66 & & & \\
\hline
\end{tabular}

The most important differences between the two groups were related to the total number of annotations made and to the mean number of annotations per student. The 20 ESO students made a total of 75 annotations while the 30 BAC students made a total of 180 annotations. For the ESO students, the average was 3'75 annotations per student $\left(\mathrm{SD}=2^{\prime} 66\right)$ while for the Bachillerato students the mean was almost double, i.e., 6 annotations per student $\left(\mathrm{SD}=2{ }^{\prime} 98\right)$. This indicated that the BAC students seemed to monitor their production to a greater extent than the ESO students.

\section{RQ3: Which aspects of writing concerned students the most?}

Six basic content categories were identified across groups: lexis, syntax, spelling, discourse organization, punctuation and topic. As can be seen in Table 3, the most frequent annotations were by far those of a lexical nature $(79,61 \%)$, followed by syntax $(9,80 \%)$, spelling $(7,06 \%)$, punctuation and discourse $(1,57 \%$ each) and, finally, topic $(0,39 \%)$. The table also shows that two of these categories (lexis and syntax) included various sub-categories. 
Table 3. Content of students' annotations across groups

\begin{tabular}{|c|c|c|c|}
\hline CATEGORIES & SUBCATEGORIES & $\begin{array}{c}\text { NUMBER OF } \\
\text { ANNOTATIONS }\end{array}$ & $\begin{array}{c}\text { PERCENTAGE OF ALL } \\
\text { ANNOTATIONS }\end{array}$ \\
\hline \multirow{3}{*}{ LEXIS } & Words & 155 & \\
\hline & Phrases & 29 & \\
\hline & Clauses & 18 & \\
\hline \multirow{2}{*}{ SUBTOTAL } & Sentences & 1 & \\
\hline & & 203 & $79,61 \%$ \\
\hline \multirow{5}{*}{ SYNTAX } & Prepositions & 6 & \\
\hline & Verb tense & 7 & \\
\hline & Word order & 5 & \\
\hline & Articles & 3 & \\
\hline & Word form & 4 & \\
\hline SUBTOTAL & & 25 & $9,8 \%$ \\
\hline SPELLING & & 18 & $7,06 \%$ \\
\hline PUNCTUATION & & 4 & $1,57 \%$ \\
\hline DISCOURSE & & 4 & $1,57 \%$ \\
\hline TOPIC & & 1 & $0,39 \%$ \\
\hline TOTAL & & 255 & $100 \%$ \\
\hline
\end{tabular}


In the following, some examples are given of the categories and subcategories of annotations.

1. Lexical annotations. In determining the types of lexical annotations, the data indicated that a distinction should be established between lexical concerns at word level, the most frequent ones, and beyond word level. Lexical concerns beyond word level were further distinguished at phrase, clause and sentence level:

A. At word level

\section{Student text \\ "...I would donate the money to ___countries.” \\ B. At phrase level}

\section{Student text \\ "I feel poor countries" \\ C. At clause level}

\section{Student text \\ "I would buy to my parents a big house because \\ D. At sentence level}

\section{Student text}

"I will never win the lottery, but

\section{Annotation}

"No sé decir subdesarrollados"

\section{Annotation}

"No sé decir lástima por ellos"

\section{Annotation}

"No sé cómo decir se lo merecen"

2. Syntactic annotations. When determining the type of syntactic annotations, the data reflected that students had similar concerns in relation to prepositions, verb tenses, word order or sentence structure, articles and word fom.

\section{A. Preposition}

\section{Student text}

"If I won the lottery, I would

help __ poor people"

B. Verb tense

\section{Student text Annotation}

"If I won the lottery, I buy a car"

“Sería can o could?”

C. Word order / sentence structure

\section{Student text}

"Si ganara la lotería, compraría unos

\section{Annotation}

"No sé cómo estructurar la frase"

\section{Annotation}

“Sería help on o help to?” vehículos, dos o tres motos y cuatro o

cinco coches que luego tunearía." 
D. Articles

\section{Student text}

"If I won the lottery, I would buy cargament of sweets."

E. Word form

\section{Student text}

"...I would help the less lucky people"

\section{Annotation}

“¿Sería a o the?”

\title{
3. Spelling.
}

\section{Student text}

"If I won the lottery, I would be independent..."

\section{Annotation}

“Está bien el superlativo de inferioridad?”

\section{Punctuation.}

\section{Student text}

"To sum up I would help..."

\author{
Annotation \\ "No sé si detrás de to sum up iría una \\ coma"
}

\section{Discourse organization.}

\section{Student text}

\section{Annotation}

"No sé si, en general, mi redacción está bien estructurada."

\section{Topic.}

\section{Student text}

\section{Annotation}

"Me ha costado bastante escribir sobre este tema."

\section{RQ4: What are the similarities and differences in the content of the annotations made secondary school students at different levels of proficiency?}

Similarities and differences in the frequency of the annotations made by the ESO and the BAC students were found. Table 4 shows the raw frequency of annotations in each category as well as the percentage of the total number of annotations made by each group of students. Both groups annotated most frequently on lexis, followed by syntax and spelling. The ESO students did not make any annotations on discourse or topic but the BAC students did, although in a very small percentage. 
Table 4. Content of ESO and BAC students' annotations

\begin{tabular}{|c|c|c|c|c|}
\hline \multirow{2}{*}{ CATEGORY } & \multicolumn{2}{|l|}{ ESO STUDENTS ANNOTATIONS } & \multicolumn{2}{c|}{$\begin{array}{c}\text { BAC STUDENTS' } \\
\text { ANNOTATIONS }\end{array}$} \\
\cline { 2 - 5 } & NUMBER & PERCENTAGE & NUMBER & PERCENTAGE \\
\hline Lexis & 56 & $74,67 \%$ & 147 & $81,67 \%$ \\
\hline Syntax & 11 & $14,67 \%$ & 14 & $7,78 \%$ \\
\hline Spelling & 6 & $8 \%$ & 12 & $6,67 \%$ \\
\hline Punctuation & 2 & $2,67 \%$ & 2 & $1,11 \%$ \\
\hline Discourse & 0 & $0 \%$ & 4 & $2,22 \%$ \\
\hline Topic & 0 & $0 \%$ & 1 & $0 ’ 55 \%$ \\
\hline TOTAL & $\mathbf{7 5}$ & $\mathbf{1 0 0} \%$ & $\mathbf{1 8 0}$ & $\mathbf{1 0 0 \%}$ \\
\hline
\end{tabular}

When the frequencies of annotations in the lexical and syntactic sub-categories were examined, some differences between the ESO and the BAC students became apparent.

Table 5. Annotations by ESO and BAC students in the sub-categories of lexis and syntax

\begin{tabular}{|l|c|c|c|c|}
\hline \multirow{2}{*}{$\begin{array}{c}\text { SUB- } \\
\text { CATEGORIES }\end{array}$} & \multicolumn{2}{c|}{$\begin{array}{c}\text { ESO STUDENTS' } \\
\text { ANNOTATIONS }\end{array}$} & \multicolumn{2}{c|}{$\begin{array}{c}\text { BAC STUDENTS' } \\
\text { ANNOTATIONS }\end{array}$} \\
\cline { 2 - 5 } & NUMBER & PERCENTAGE & NUMBER & PERCENTAGE \\
\hline LEXIS & 38 & $67,86 \%$ & 117 & $79,59 \%$ \\
\hline Words & 9 & $16,07 \%$ & 20 & $13,61 \%$ \\
\hline Phrases & 8 & $14,29 \%$ & 10 & $6,80 \%$ \\
\hline Clauses & 1 & $1,78 \%$ & 0 & $0 \%$ \\
\hline Sentences & $\mathbf{1 0 0 \%}$ & $\mathbf{1 4 7}$ & $\mathbf{1 0 0 \%}$ \\
\hline Total & 3 & $\mathbf{1 0 0} \%$ & $21 \% 43 \%$ \\
\hline SYNTAX & 4 & $27,27 \%$ & 3 & $21 \% 43 \%$ \\
\hline Preposition & 3 & $36,37 \%$ & 3 & $14,28 \%$ \\
\hline Verb tense & $27,27 \%$ & 2 & $21,43 \%$ \\
\hline Word order & 0 & 0 & 3 & $21,43 \%$ \\
\hline Articles & 1 & $9,09 \%$ & 3 & $\mathbf{1 0 0 \%}$ \\
\hline Word form & $\mathbf{1 1}$ & $\mathbf{1 0 0 \%}$ & $\mathbf{1 4}$ & \\
\hline Total & \multicolumn{5}{|c|}{}
\end{tabular}

As shown in Table 5, the BAC students did not make any annotations on the sentence sub-category of lexis nor did the ESO students on the article sub-category of syntax. Within categories, there were also differences between groups. In the lexis category, the BAC students showed a higher percentage of annotations than the ESO students at word level $(\mathrm{ESO}=67,85 \%$; $\mathrm{BAC}=79,59 \%)$, but a lower percentage at both phrase $(\mathrm{ESO}=16,07 \%$; $\mathrm{BAC}=13,61 \%)$ and clause levels $(\mathrm{ESO}=14,29 \%$; $\mathrm{BAC}=6,80 \%)$. On the other hand, while the BAC students stroke almost a perfect balance between their syntactic concerns on prepositions, verb tenses, articles and word forms (21, 42\% each), the ESO students were found to focus their attention primarily on verb tenses $(36,36 \%)$, followed by prepositions and word order $(27,27 \%$ each) and, finally, word form $(9,09 \%)$. 


\section{Discussion}

This study was intended as an exploration of the self-monitoring practices of a group of Spanish highschool EFL learners when composing texts in their L2. The data reported above suggest that the request for translations from the L1 to the L2 was by far the most frequent form of annotation across groups. This form of annotation, which basically allowed the participants in the study to notice and monitor the ideas and the language which were important for them to write their texts, is in line with previous findings on L1 use in L2 writing. In fact, research has suggested that the L1 is used in L2 writing for a variety of purposes which include not only the planning and organization of texts, the rereading of the texts already produced and their evaluation and revision, but also the generation of ideas and the access to and retrieval of those lexical items which writers consider necessary to express their intended meanings (Wang, 2003; Murphy \& Roca de Larios, 2010). These latter two types of concerns were the ones that primarily guided the participants' requests for L2 forms through their L1. Another less frequent form of annotation involved the confirmation of the correction or appropriateness of the terms already available in the learners' linguistic repertoires, which was directly related to the unstable nature of their low-intermediate level of L2 proficiency (Manchón, Roca de Larios, Murphy, 2009).

The very reduced use of blanket requests (requests through which the student asked for all items of a particular type to be corrected or for the correction of the whole composition) is in clear contrast with some findings reported in previous studies. Storch and Tapper (1996), for example, found that this type of annotation form was abundantly used by those participants in their study who "were less effective in communicating exactly what their concerns were....(had) limited ability to locate exact instances of concern.......and (had) many errors in their writing and definitely needed help" (p. 333). Radecki and Swales (1988) also found that students at the lowest level of language proficiency failed to report what their specific concerns were. A possible explanation for the differences between these findings and those in our study may be related to the contexts in which the studies were carried out. Both Storch and Tapper (1996) and Radecki and Swales (1988) carried out their studies in ESL contexts where the multiplicity of concerns to be borne in mind by the writers while composing their texts probably led some of them to report their problems at a very low level of specificity and, consequently, to rely more on blanket requests. This multiplicity of concerns, however, is not typical of EFL school writing and this probably gave the participants in our study the possibility of focusing their attention on more specific issues.

Our data also indicate that there were no differences between groups in the order in which the participants favoured their annotation forms. Asking the teacher for the translation of an item previously formulated in the L1 came first, a request for the correction of either a translation or an L2 form were the next two anotation forms, a request for the correction of two alternatives and asking for another way of saying something came fourth and fith respectively, and finally, blanket requests came last. We can conclude, therefore, that the ESO and the BAC students' difference in their L2 proficiency did not have any bearing on their list of priorities related to annotation forms, although it did on the average number of annotations per student. As reported above, 
the BAC students' mean number of annotations $(\mathrm{M}=6 ; \mathrm{SD}=2,98)$ was almost double than that of the ESO students $(\mathrm{M}=3,75 ; \mathrm{SD}=2,66)$, a result which shows that the purported higher proficiency of the former allowed them to notice and monitor their production to a greater extent than the latter. This finding corroborates other studies showing that the proficiency level of learners may affect the quantity of their noticing processes (Qi \& Lapkin, 2001).

As for the areas of writing which concerned the students most, it was found that their attention was mainly focused on lexical and, to a lesser extent, syntactic elements. Most lexical annotations were made as attempts to make up for the participants' lack of lexical knowledge in accessing the necessary items or because they were hesitant as to their correctness or appropriateness, a result which is in line with similar findings related to the formulation of ideas through the selection of appropriate words (Murphy \& Roca de Larios, 2010). Although the frequency of syntactic annotations was sensibly lower than that of lexical annotations across groups (25 syntactic versus 203 lexical entries), their importance has also been emphasized by some studies that have shown that L2 writers tend to restructure the constituents of their sentences and clauses and search for alternatives when difficulties arise (Manchón et al., 2009).

The reason why both groups annotated most frequently on lexis could be attributed to the fact that it was left up to the participants to register any type of problems they encountered when writing the composition. Given this situation, it was probably easier for them to express concerns with lexis than locating and articulating concerns about grammar (Storch \& Tapper, 1997). Furthermore, as the participants were writing their first drafts, it is only logical that they concentrated their attention on the ideational and lexical aspects of their compositions, a finding that has also been reported in previous studies (Ellis, 2001; Swain \& Lapkin, 1995; Williams, 2001).

Finally, the BAC students made a small percentage of annotations on discourse and to a lesser extent on topic while the ESO students did not. The difference could be explained by the fact that the former, as against the latter, were receiving tuition on global analyses of L2 texts and carried out activities through which they were expected to pay attention to composition topics.

\section{Conclusions and Pedagogical implications}

This study has shown that the annotation scheme may be used as a reliable tool to gather information about secondary school students' L2 writing concerns. Informal conversations with the teacher and the students' responses to the abovementioned questionnaires confirm this claim. The teacher said that she saw the technique as a useful tool to know about students' specific feedback needs whose application required no extra time or effort. She pointed out, however, that the hard work would come later when she had to adjust her feedback to the students' needs.

Most students, in turn, claimed that they regarded the self-monitoring technique as very useful because it helped them (i) realize what aspects to pay attention to; (ii) gain self-confidence; (iii) take risks such as experimenting with subordination, for instance; (iv) make clear to the teacher their writing intentions. 
As annotations highlight the areas which concern the students most, the teacher can provide individualized feedback to the needs identified by the students themselves. At the same time, if systematically repeated, the technique may allow learners to become more critical evaluators of their own writing and teachers to gain awareness of the areas in need of additional attention in class. In the case of the participants in our study, they might benefit from more attention being payed, for example, to concerns beyond the sentence level.

In fact, the data showed that the participants did not report any concerns beyond the sentence level. In spite of the differences in proficiency between the groups, none of the writers in the study showed real higher level concerns about the quality of ideas, the coherence of their texts or the clarity of the expressions used. This lack of textual concerns could be attributed to the nature of the task itself, the time for task completion or the students' level of L2 proficiency. It could also be regarded as a by-product of the correction habits induced among the students over the years. The students were probably used to receiving feedback only on lexical and grammatical aspects of their compositions and, as a result, they tended to perceive these problems as those which were of paramount importance in writing. For all these reasons, the importance of this finding should not be underestimated. Its main pedagogical implication is that if teachers continue to use methodological practices that do not allow learners to notice areas of concern beyond the sentence level, they will not be helping their students become real "text" writers. As an alternative, students might be encouraged to make their annotations on computers. This procedure would turn annotations visible and would allow both teachers and learners (individually and in groups) to respond to them paying more attention to textual concerns.

Finally, a number of pedagogical implications to be analyzed in future research are related to how students' annotations may (i) function with learners at a wider range of proficiency levels than those analyzed in the present study, (ii) affect teachers' feedback comments and the quality and nature of the resulting texts, (iii) serve as a mediating tool to help learners improve their writing skills in the long run. In any case, as suggested by Storch and Tapper (1996), the real challenge for teachers is to help their students at different levels of writing skill and L2 proficiency use the annotation scheme effectively.

\section{REFERENCES}

Adams, R. (2003). "L2 output, reformulation and noticing: implications for IL development", in Language Teaching Research, 7, 3: 347-76.

Cohen, A.D. \& Cavalcanti, M.C. (1990). "Feedback on written compositions: Teacher and student verbal reports", in B. Kroll (Ed.), Second language writing: Research insights for the classroom. Cambridge: CUP, 155-177.

Conrad, S.M. \& Goldstein, L.M. (1999). "ESL learner revision after teacher-written comments: Text, contents, and individuals", in Journal of Second Language Writing, 8, 2: 147-179.

Cresswell, A. (2000). "Self-monitoring in student writing: developing learner responsibility", in ELT Journal, 54, 3: 235-244.

Cumming, A., Busch, M., \& Zhou, A. (2002). "Investigating learners' goals in the context of adult 
second-language writing", in S. Ransdell \& M. Barbier (Eds.), New directions for research in L2 writing. Dordrecht, Netherlands: Kluwer, 189-208.

Ellis, R. (2001). "Introduction: investigating form-focused instruction", in Language Learning, 51 (Suppl.1), 1-46.

Ellis, R., Sheen, Y., Murakami, M., \& Takashima, H., (2008). "The effects of focused and unfocused written corrective feedback in an English as a foreign language context", in System, 36, 3: 353-371.

Ferris, D. (2004). "The 'grammar correction' debate in L2 writing: Where are we, and where do we go from here? (and what do we do in the meantime...?)", in Journal of Second Language Writing, 13, 1: 49-62.

Goldstein, L. M. (2004). "Questions and answers about teacher written commentary and student revision: teachers and students working together", in Journal of Second Language Writing, 13, 1: 63-80.

Goldstein, L. (2006). "Feedback and revision in second language writing: Helping learnersbecome independent writers", in K. Hyland \& F. Hyland (Eds.), Feedback in second language writing: Contexts and issues. New York : CUP, 185-205.

Hedgcock, J., \& Lefkowitz, N. (1994). "Feedback on feedback: assessing learner receptivity to teacher response in L2 composing", in Journal of Second Language Writing, 3, 2: 141-163.

Hyland, F. (1998). "The impact of teacher-written feedback on individual writers", in Journal of Second Language Writing, 7, 3: 255-288.

Hyland, F. (2003). "Focusing on form: student engagement with teacher feedback", in System, 31, 217-230.

Leki, I. (1990). "Coaching from the margings: Issues in written response", in B. Kroll (Ed.), Second Language Writing. Cambridge: CUP, 57-68.

Leki, I. (1991). "The preferences of ESL students for error correction in college-level writing classes", in Foreign Language Annals, 24, 3: 203-218.

Manchón, R. M., Roca de Larios, J., \& Murphy, L. (2009). "The temporal dimension and problem-solving nature of foreign language composing processes: Implications for theory", in R.M. Manchón (Ed.), Writing in foreign language contexts: Learning, teaching, and research. Clevedon, UK: Multilingual Matters, 102-129.

Murphy, L. \& Roca de Larios, J. (2010). "Searching for words: One strategic use of the mother tongue by advanced Spanish EFL writers", in Journal of Second Language Writing, 19, 2: 61-81.

Qi, D. S. \& Lapkin, S. (2001). "Exploring the role of noticing in a three-stage second language writing task", in Journal of Second Language Writing, 10, 4: 277-303.

Radecki, P. M. \& Swales, J. M. (1988). "ESL student reaction to written comments on their written work", in System, 16, 3: 355-365.

Robinson, P. (1995). "Review article: Attention, memory and the "noticing" hypothesis", in Language Learning, 45, 2: $283-331$.

Robb, T., Ross, S., \& Shortreed, I. (1986). "Salience of feedback on error and its effect on EFL writing quality", in TESOL Quarterly, 20, 1: 83-93.

Sachs, R. \& Polio, C. (2007). "Learners' uses of two types of written feedback on a L2 writing revision task", in Studies in Second Language Acquisition, 29, 1: 67-100.

Schmidt, R. (2001). "Attention", in P. Robinson (Ed.), Cognition and Second Language Instruction. Cambridge: Cambridge University Press, 3-32.

Sharwood Smith, M. (1991). "Speaking to many minds: On the relevance of different types of language information for the L2 learner", in Second Language Research, 7, 2: 118-132. 
Storch, N. \& Tapper, J. (1996). "Patterns of NNS student annotations when identifying areas of concern in their writing", in System, 24, 3: 323-336.

Storch, N. \& Tapper, J. (1997). "Student Annotations: What NNS and NS university students say about their own writing", in Journal of Second Language Writing, 6, 3: 245-264.

Storch, N. \& Wigglesworth, G. (2010). "Learners' processing, uptake, and retention of corrective feedback on writing", in Studies in Second Language Acquisition, 32, 2: 303-334.

Swain, M. (1995). "Three functions of output in second language learning", in G. Cook \& B. Seidlhofer (Eds.), Principle and practice in applied linguistics. Oxford: OUP, 125-144.

Swain, M. \& Lapkin, S. (1995). "Problems in output and the cognitive processes they generate: A step towards second language learning", in Applied Linguistics, 16, 3: 71-391.

Truscott, J. (1996). "The case against grammar correction in L2 writing classes", in Language Learning, 46, 2: 327-369.

Van Beuningen, C. (2010). "Corrective feedback in L2 writing: Theoretical perspectives, empirical insights, and future directions", in International Journal of English Studies, 10, 2: 1-27.

Wang, L. (2003). "Switching to first language among writers with differing second-language proficiency", in Journal of Second Language Writing, 12, 4: 347-375.

Williams, J. (2001). "Learner-generated attention to form", in R. Ellis (Ed.), Form-focused instruction and second language learning. Malden, MA: Blackwell, 303-346.

Xiang, W. (2004). "Encouraging self-monitoring in writing by Chinese students", in ELT Journal, 58, 3: 238-246.

Zamel, V. (1983). "The composing processes of advanced ESL students: six case studies", in TESOL Quarterly, 17, 2: 165-87.

Zhang, S. (1995). "Reexamining the affective advantage of peer feedback in the ESL writing class", in Journal of Second Language Writing, 4, 3: 209-222. 